\title{
The Immunizing Antigens of Erysipelothrix rhusiopathiae. The Role of the L-Antigen
}

\author{
By A. W. GLEDHILL \\ National Institute for Medical Research, Mill Hill, London, N.W. 7
}

SUMMARY: Vaccines were prepared by formolizing cultures of Erysipelothrix rhusiopathiae and precipitating with aluminium hydroxide gel (AG). Fifty per cent of mice were protected against about a thousand lethal doses. 'Two (Ru and VYS) of eleven strains yielded highly potent vaccines.

Serum in the medium increased the potency of vaccines and for one of the strains liver extract was needed in the medium to give potent vaccines. In general, vaccines protected well against heterologous strains but protection was relatively poor against one of these.

A soluble antigen present in culture fluids induced in rabbits antibodies protecting mice and agglutinating suspensions of $E$. rhusiopathiae grown in the presence of serum. This soluble antigen was thermo-labile. In these respects it resembles the $L$-antigen, differing only in being detached from the surface of cells. Soluble antigen was precipitated with AG, yielding fairly good vaccines. Cells freed from media were also precipitated, yielding rather better vaccines. It is suggested that cells yield vaccines of high potency when they have produced and retained a relatively large amount of $L$-antigen.

Merthiolate-killed cells of Erysipelothrix rhusiopathiae grown in serum-containing media are capable of inducing in rabbits circulating antibodies protective for mice (Gledhill, 1947). Preliminary experiments with pigs indicated that whereas some circulating antibodies were also produced by intravenous injection of killed cells, a stronger response was elicited by suspensions of formalin-killed cultures from which most of the cells had been removed by centrifugation (Gledhill, 1948). Traub (1947) showed that mice and pigs could be actively immunized with cultures precipitated with aluminium hydroxide and that both cells and a soluble antigen present in cultures were necessary for producing fully active vaccines. Moreover, such active vaccines were only produced by a few strains of $E$. rhusiopathiae. However, Traub did not give the technical details of his methods. The purpose of this investigation is (1) to confirm that killed vaccines precipitated by aluminium hydroxide gel immunize mice effectively; $(2)$ to confirm the existence of Traub's soluble antigen; (3) to determine its relationship to the $\mathrm{L}$-antigen developed on the surface of cells grown in serum-containing media (Gledhill, 1947).

\section{ME'THODS}

Maintenance of strains. In general, strains were maintained on serum agar slopes and subcultured at monthly intervals. Good immunizing strains were lyophilized. Strains for challenging mice were passaged through normal mice at frequent intervals and cultures made on serum agar slopes were kept at 
$4^{\circ}$ and used when not more than 3 days old for seeding cultures for challenging mice.

Media. Meat infusion broth prepared from horse flesh and Wright's (1933) infusion broth referred to as $\mathrm{HW}$ broth, were used. For ordinary vaccine production $2-2.5 \%(\mathrm{v} / \mathrm{v})$ horse serum was added to $\mathrm{HW}$ broth. For some vaccines, $10 \%$ extract of fresh ox liver was also incorporated.

Preparation of aluminium hydroxide gel $(A G)$. Solution $1: 300 \mathrm{~g}$. ammonium sulphate were dissolved in $340 \mathrm{ml}$. hot distilled water, cooled to $60^{\circ}$ and then filtered. Solution 2: $25 \mathrm{~g}$. aluminium sulphate were dissolved in $100 \mathrm{ml}$. boiling distilled water and allowed to cool to $60^{\circ}$. To solution 1 was added $80 \mathrm{ml}$. conc. ammonia (sp.gr. $0 \cdot 880$ ) and then solution 2 was added immediately and stirred for $15 \mathrm{~min}$. The precipitate was washed with distilled water, with $0.012 \mathrm{~N}-\mathrm{HCl}$ and again with distilled water. The $\mathrm{pH}$ value was adjusted to $7 \cdot 6$ and the precipitate taken up in $60 \mathrm{ml}$. distilled water and autoclaved.

Preparation of vaccines. Horse serum $\mathrm{HW}$ broth or medium modified as stated in the text, was warmed to $37^{\circ}$ and seeded with the appropriate strain. After $20-24 \mathrm{hr}$. incubation at $37^{\circ}$, when the opacity of the culture was about equal to that of a no. 2 Brown's tube (Burroughs Wellcome and Co., London) formalin to $0 \cdot 4-0.5 \%(\mathrm{v} / \mathrm{v})$ was added and the whole allowed to stand in the laboratory for $24 \mathrm{hr}$. The culture was then tested for sterility and put at $4^{\circ}$ for another $24 \mathrm{hr}$. For every $100 \mathrm{ml}$. medium, $4 \mathrm{ml}$. AG were added and well mixed in, followed by another $1 \mathrm{ml}$. AG a few hours later. After standing a further $18 \mathrm{hr}$. at $4^{\circ}$, the material was lightly centrifuged to pack the deposit and the clear supernatant withdrawn. In the earlier vaccines $95 \mathrm{ml}$. supernatant were withdrawn but in later vaccines $90 \mathrm{ml}$. were withdrawn to give about $10 \mathrm{ml}$. vaccine for every $100 \mathrm{ml}$. medium. The completed vaccine was tested for sterility.

Filtration of cultures. Liquid media were centrifuged at 3000 r.p.m. for $\frac{1}{2} \mathrm{hr}$. and the supernatant filtered with positive pressure through a Gradocol membrane of average pore diameter (APD) $1 \cdot 0 \mu$. standing on a finer membrane of APD 0.6 or $0.7 \mu$. as required. For filtration through finer membranes of APD $0 \cdot 2$ and $0 \cdot 1 \mu$., the supernatant fluid was first filtered through membranes of APD $1 \cdot 0 \mu$. and $0 \cdot 6-0 \cdot 7 \mu$., as described, and the filtrate was then passed through the finer membranes. In this way, $100 \mathrm{ml}$. volumes were obtained from one set of filters. To filter $5 \mathrm{ml}$. quantities it was possible to omit the centrifugation. Filtrates were usually treated with formalin as an added precaution of sterility.

Immunization of rabbits. Rabbits were immunized by four intravenous injections at 4 -day intervals and bled 10 days after the last injection. For this purpose, filtrates were given in 1, 2, 3 and $3 \mathrm{ml}$. doses and cells, standardized to Brown's no. 3 tube and suspended in $0.5 \%$ formol saline, in $\frac{1}{2}, 1,1 \frac{1}{2}$ and $1 \frac{1}{2} \mathrm{ml}$.

Tests of vaccines in mice. Groups of mice (16-18 g.) were injected subcutaneously in the back, each mouse with a $\mathbf{0 . 2} \mathrm{ml}$. dose of fourfold dilutions of vaccine from $1 / 1$ to $1 / 1024$. Dilutions of vaccine were made with undiluted AG in early experiments and afterwards with AG diluted 1/2 with sterile 
water. Controls were set aside and, in many cases, injected with the same dose of diluted AG. It soon became clear that AG had no effect upon resistance to subsequent challenge. Fourteen days after vaccination, mice were challenged with the appropriate strain, usually the homologous one. The challenge strain was seeded from a serum agar culture (as already described) to $50 \mathrm{ml} .1 \%(\mathrm{v} / \mathrm{v}$ ) serum HW broth. After growing the culture for 18-21 hr., it was centrifuged and the organisms suspended in HW broth to an opacity equal to Brown's tube no. 8. Tenfold dilutions were then made in HW broth to give a final suspension of opacity $10^{-4} \times$ Brown's tube no. 8 . This suspension was then injected intraperitoneally $0.5 \mathrm{ml}$./mouse, the cells present representing more than $10^{3}$ M.L.D. Sickness and deaths of mice were recorded daily for 14 days, when the experiments were terminated. As few mice which became sick recovered, results are given in terms of mortalities only. The majority of mice which died did so within 1 week. For a satisfactory test the controls should die within 4-5 days. When this time of survival is greatly exceeded, the results tend to become erratic, sick mice often recovering without relation to the dilution of vaccine which they had received. In some cases the mortalities for each dilution of vaccine have been set out in tables but in the majority of cases the results have been expressed as the PD 50, that is the reciprocal of the dilution of vaccine giving $50 \%$ survival of mice, calculated according to the method of Reed \& Muench (1938).

Tests of rabbit sera in mice. Mice (18-20 g.) were injected with rabbit sera intraperitoneally. For tests of sera from rabbits immunized with culture filtrates, the dose given to each mouse was $0.3 \mathrm{ml}$., since the purpose was to detect protective antibodies in rabbits which had received minimal quantities of antigen. For tests of sera against suspensions of killed cells, the dose given was $0.1 \mathrm{ml}$. serum diluted with $0.2 \mathrm{ml}$. saline, to give a gross dose of $0.3 \mathrm{ml}$. as before. Twenty-four hr. later, mice were challenged by intraperitoneal inoculation of the dose of cells used for challenging vaccinated mice. The effects of challenge were recorded in the same way as for the challenge of vaccinated mice.

Agglutination tests. These were carried out according to the technique previously described by Gledhill (1945).

\section{EXPERIMENTAL}

\section{The preparation of effective killed vaccines}

Preliminary selection of strains. Vaccines were prepared against nine strains of $E$. rhusiopathiae from growth obtained by cultivation for $24 \mathrm{hr}$. in $50 \mathrm{ml}$. medium made up as follows: meat broth, $40 \mathrm{ml}$; glucose, 0.5 g.; Hartley's broth, $5 \mathrm{ml}$; ; sodium oleate, $\mathbf{3 . 0} \mathrm{mg}$.; serum ultrafiltrate, $5 \mathrm{ml}$.

This medium was used because it contained no serum and yet showed some capacity to grow bacterial cells which, after killing with formalin, were able to produce circulating protective antibodies when injected into rabbits. The growths, of opacity about equal to no. 1 Brown's tube, were treated with formalin $(0.5 \%, \mathrm{v} / \mathrm{v})$, allowed to stand at room temperature for $24 \mathrm{hr}$, , tested 
for sterility and precipitated at $4{ }^{\circ}$ with $2 \mathrm{ml}$. aluminium gel preparation (AG). After light centrifuging the supernatant was decanted to give $2.5 \mathrm{ml}$. vaccine. These vaccines were then diluted $1 / 4$ and $1 / 16$ with $A G$ and injected subcutaneously into the backs of mice in $0.2 \mathrm{ml}$. doses. Fourteen days later, the mice, together with normal controls, were challenged with about 1000 lethal doses of the homologous strain. It will be seen from Table 1 that the vaccine made with strain $\mathrm{Ru}$ was sharply divided from the rest in its capacity to prevent the death of four out of five mice at dilution $1 / 4$ and three out of six mice at dilution 1/16. Of the other vaccines, perhaps those from $\mathrm{EW} 16$ and CS showed some slight activity in lengthening the survival time of vaccinated mice, as compared with controls; the remaining six gave no evidence of any activity.

Table 1. The activity of vaccines from nine unselected strains

\begin{tabular}{|c|c|c|c|c|c|c|}
\hline \multirow[b]{3}{*}{$\begin{array}{c}\text { Strain } \\
\text { designation }\end{array}$} & \multicolumn{4}{|c|}{ Vaccine dilutions } & \multirow{2}{*}{\multicolumn{2}{|c|}{ Control mice }} \\
\hline & $1 / 4$ & $1 / 16$ & $1 / 4$ & $1 / 16$ & & \\
\hline & \multicolumn{2}{|c|}{ No. mice dying/group } & \multicolumn{2}{|c|}{ Av. time to death (days) } & $\begin{array}{c}\text { No. mice } \\
\text { dying/group }\end{array}$ & $\begin{array}{l}\text { Av. time to } \\
\text { death (days) }\end{array}$ \\
\hline $\mathrm{Ru} \mathrm{1/50}$ & $1 / 5$ & $3 / 6$ & $6 \cdot 0$ & $3 \cdot 3$ & $5 / 5$ & $2 \cdot 8$ \\
\hline $\mathrm{CS}$ & $6 / 6$ & $6 / 6$ & $6 \cdot 5$ & $6 \cdot 1$ & $6 / 6$ & $3 \cdot 8$ \\
\hline EW 16 & $3 / 4$ & $5 / 5$ & $6 \cdot 3$ & $4 \cdot 0$ & $6 / 6$ & $4 \cdot 6$ \\
\hline $\mathbf{R}$ & $5 / 5$ & $6 / 6$ & $5 \cdot 4$ & $4 \cdot 0$ & $6 / 6$ & $4 \cdot 0$ \\
\hline EW 24 & $4 / 4$ & $6 / 6$ & $2 \cdot 8$ & $\mathbf{3} \cdot \mathbf{3}$ & $6 / 6$ & $2 \cdot 8$ \\
\hline MEW 22 & $4 / 4$ & $6 / 6$ & $3 \cdot 5$ & $\mathbf{3} \cdot \mathbf{3}$ & $8 / 8$ & $3 \cdot 0$ \\
\hline Chile & $5 / 5$ & $6 / 6$ & $4 \cdot 0$ & $7 \cdot 1$ & $6 / 6$ & $5 \cdot 3$ \\
\hline Rox & $3 / 3$ & $6 / 6$ & $4 \cdot 3$ & $2 \cdot 5$ & $5 / \tilde{5}$ & $4 \cdot 2$ \\
\hline WW 1 & $5 / 5$ & $6 / 6$ & $2 \cdot 2$ & $\mathbf{3} \cdot \mathbf{0}$ & $6 / 6$ & $3 \cdot 0$ \\
\hline
\end{tabular}

Mice were injected $0.2 \mathrm{ml}$. subcutaneously dilutions of vaccine made in AG and challenged 14 days later with the usual challenge dose of the homologous strain.

The influence on vaccines of serum in the medium. In a subsequent experiment using two vaccines ( $R$ u $2 / 50$ and $3 / 50$ ) prepared from strain $\mathbf{R u}$ grown in another batch of the above complex medium, growth was delayed, although after $48 \mathrm{hr}$. the opacity was equal to about no. 1 Brown's tube. Tests with both these vaccines showed neither to have any activity whatsoever, whereas the activity of the original vaccine $R u$ 1/50 was confirmed, none dying of five mice immunized with vaccine diluted $1 / 64$. The delay in growth suggested that the failure of these two vaccines may have been due to the unsuitability of the medium. A vaccine ( $R u$ 4/50) was therefore prepared using $2 \%(v / v)$ serum HW broth and this was found to stimulate protective antibody even when diluted $\mathbf{1 / 2 5 6}$. The question was further tested by preparing another vaccine ( $R u$ 5/50) in the original medium and comparing it with a vaccine ( $\mathrm{Ru} \mathrm{6/50)}$ prepared at the same time in medium in which the $5 \mathrm{ml}$. serum ultrafiltrate were replaced by $2 \mathrm{ml}$. serum and $3 \mathrm{ml}$. water. The PD 50's were 8 for vaccine

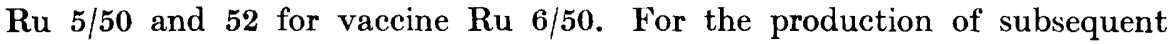
vaccines, horse serum was incorporated into the medium and, using strain $\mathbf{R u}$, all proved consistently satisfactory. The number of these vaccines is twelve, representing productions of vaccine on five separate occasions during a period of 12 months. Furthermore, three satisfactory vaccines have been 
prepared independently by Mr A. Thomson, M.R.C.V.S., of the Wellcome Research Laboratories, Beckenham, with a view to immunizing pigs.

It was observed that the rate of growth of the mice given vaccine was less than the rate of normal mice and some of the vaccinated mice died. To meet this difficulty all vaccines after $R \mathbf{R} 6 / 50$ prepared by precipitation with AG were made to a final volume of $10 \mathrm{ml} . / 100 \mathrm{ml}$. medium, instead of $5 \mathrm{ml} . / 100 \mathrm{ml}$. medium. Also, in testing them with mice, dilutions were carried out with the AG diluted $1 / 2$ with water.

Influence of liver extract in the medium for vaccine production. Using another strain of organism (VYS), obtained from Dr A. W. Stableforth and believed to be derived from that used for vaccine production in Yugoslavia, one vaccine was prepared using $2 \frac{1}{2} \%(\mathrm{v} / \mathrm{v})$ serum HWB medium (vaccine VYS 6/51) and another using medium prepared from $20 \%$ ox liver and $80 \%$ horse meat, instead of horse meat only (vaccine VYS 8/51). The PD 50's against the homologous strain were 7 for VYS 6/51 and 256 for VYS 8/51, showing the advantage of liver extract in preparing vaccine with strain VYS. On the other hand, with otherwise similar batches of media made with and without liver, and inoculated with strain $\mathrm{Ru}$, the PD 50's were 47 for the vaccine from medium containing liver extract and more than $\mathbf{2 5 6}$ for vaccine from the medium not containing liver. This suggests that liver extract in the medium had no advantage in the case of strain Ru. Another vaccine prepared with strain VYS using $2 \frac{1}{2} \%(\mathrm{v} / \mathrm{v})$ serum HW broth to which was added $10 \%$ beef liver extract had a PD50 of 26, confirming that the strain was capable of producing reasonably efficient vaccines.

The results of the experiments described show that the production of effective vaccines greatly depends upon the constitution of the medium used and that there may be differences between the growth requirements of different strains. Most strains appear incapable of giving effective vaccines, thus confirming the work of Traub (1947). Nevertheless, it might well be that of the nine strains originally tested, more than one would have yielded an efficient vaccine if the medium had contained serum and liver extract. A vaccine prepared with strain EW 24 grown in $2 \frac{1}{2} \%(\mathrm{v} / \mathrm{v})$ serum $\mathrm{HW}$ broth had a PD50 of 4, whereas vaccine prepared with this strain grown in the original medium containing no serum gave no protection to mice at a dilution of 1/4 (see Table 1).

It has been stated that some strains agglutinate fowl red blood cells and that among these strains are to be found those which can produce vaccines (Dinter, 1948; Bakos, 1951). In a limited number of tests, it was found that agglutination depended not only upon the strain of organism used but also upon the particular fowl giving the red blood cells, and upon the medium used for growth. The few tests carried out did not seem to confirm the value of haemagglutination for the selection of good vaccine-producing strains.

The effect of filtration. On occasions cells of $E$. rhusiopathiae have passed through bacterial filters during the preparation of biological products and this has led to disastrous results (Edwards, 1949; Rowlands \& Edwards, 1950). The filtrability of the strains of the organism was tested primarily to determine 
whether the antigen present in supernatants after centrifuging and treating with formalin (Gledhill, 1948) and after filtration (Traub, 1947) might really be small filter-passing cells (Gledhill, 1950).

Cultures in HW broth were filtered through Gradocol membranes of APD $0 \cdot 6-1 \cdot 0 \mu$. and $5 \mathrm{ml}$. filtrate were used to inoculate $30 \mathrm{ml}$. of the same medium. Of eleven strains tested in this way, growths appeared in seven filtrates through membranes of $0 \cdot 8 \mu$. APD or less. Re-tests, when performed, gave consistent results except in the case of one strain (Chile); details of these filtrations are shown in Table 2. The question as to whether filter-passing cells are solely responsible for the antigenic activity of filtrates is considered later. Here, it is noted that a vaccine prepared from strain CS had a PD50 of 20 when growth was initiated from filtrate, whereas inoculation of unfiltered organisms into the batch of medium yielded a vaccine with a PD50 of 4 . It is also of interest that strain EW 2 with which the antigenic activity of supernatant after centrifugation and sterilization was first observed (Gledhill, 1948) and which subsequently lost this activity, was not then filtrable through a membrane of APD $0.8 \mu$. or less. However, growth from an ampoule of this strain dried in 1942 was found to be filtrable. Vaccines prepared from growths from filtrates and from ordinary seeding of lyophilized culture both had a PD 50 of 25. There are therefore indications that filtrability may have some bearing upon vaccine production. The explanation might be that a majority of cells fully in the $S$-phase are required for vaccine production and that such cells are more filtrable than $\mathrm{R}$-forms. If this be so, occasional filtration of vaccine-producing strains, and seeding of medium with such filtrates might tend to prevent loss of power to yield active vaccines.

Table 2. The filtrability of strains of E. rhusiopathiae

$\begin{array}{lcc}\begin{array}{c}\text { SPD of } \\ \text { Strain }\end{array} & \begin{array}{c}\text { Gradocol } \\ \text { membrane } \\ (\mu .)\end{array} & \begin{array}{c}\text { No. of filtrates } \\ \text { not sterile/no. } \\ \text { filtrations } \\ \text { performed }\end{array} \\ \text { Ru } & 0 \cdot 76,0 \cdot 8 & 2 / 2,2 / 2 \\ \text { VYS } & 0 \cdot 68 & \mathbf{3} / \mathbf{3} \\ \text { EW2 } & 0 \cdot 8 & 0 / 2 \\ \text { MEW 22 } & 0 \cdot 8 & 1 / 1 \\ \text { EW 16 } & 0 \cdot 8 & 0 / 2 \\ \text { EW24 } & 0 \cdot 8 & 1 / 1 \\ \text { R } & 0 \cdot 8 & 0 / 1 \\ \text { Rox } & 0 \cdot 8 & 0 / 1 \\ \text { CS } & 0 \cdot 8 & 2 / 2 \\ \text { Chile } & 0 \cdot 8 & 1 / 3 \\ \text { WW 1 } & 0 \cdot 8 & 1 / 1\end{array}$

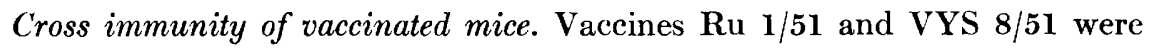
injected as usual into groups of mice which were challenged fourteen days later with the usual dose of strains Ru, VYS, EW 2, V and CYS. Strains EW 2 and $V$ were selected because they are virulent representatives of groups II and III respectively, whereas $\mathrm{Ru}$ belongs to group I, the classification being based upon quantitative somatic antigens (Gledhill, 1945). The 
group of VYS and CYS has not been determined; CYS was selected as being the strain used in Yugoslavia for testing in mice vaccines prepared with strain VYS. The results are shown in Table 3 . It will be seen that with the exception of vaccinated mice challenged with CYS, both vaccines protected against heterologous strains, even when highly diluted. The tests were carried out over a period of $2 \frac{1}{2}$ months during which time the vaccines were stored at $4^{\circ}$.

\section{The existence and relationship to L-antigen of soluble antigen present in culture fluids}

The existence of soluble antigen. The existence of a soluble antigen was suspected when it was found that formolized supernantants obtained by centrifuging cultures of strain EW 2 were not only capable of stimulating rabbits to produce protective antibodies but also pigs, in which animals the bacterial cells themselves produced few antibodies (Gledhill, 1948). Traub (1947), however, claimed to have established the existence of a soluble antigen capable of adsorption and precipitation by AG. Vaccines so produced immunized mice although not usually at so high a dilution as vaccines prepared by the precipitation of cells. The best vaccines resulted from the precipitation of both soluble substance and cells. As already remarked, the filtrability of E. rhusiopathiae suggested the possibility that the antigenic activity of sterilized supernatants might be due to the small undeposited cells in them. This possibility seemed to receive confirmation from the high antigenic activity of small cells obtained by high-speed centrifugation (20,000 r.p.m. for $1 \mathrm{hr}$.) of supernatants obtained after ordinary centrifugation. This activity was found, however, to be no greater than that of an approximately equal number of cells deposited by slow centrifugation. Furthermore, if sterilized supernatants were antigenic in virtue of the small cells in them, filtrates might be expected to be antigenic in virtue of the viable small cells in them, even though very few in number (Gledhill, 1950). In earlier tests with strain EW 2, formolized filtrates did not have any antigenic activity, but later tests with strains Ru and VYS showed them to possess sufficient antigenic activity to produce, at the doses used, a measurable amount of circulating antibody in rabbits (Tables 4 and 6 ). In the following section it is further shown that sterile filtrates treated with AG yielded a precipitate capable of immunizing mice, thus confirming 'Traub's claim.

The relationship of soluble antigen to L-antigen. Thermolabile L-antigen produced on the surface of cells grown in media containing serum and inactivated with merthiolate, evokes in rabbits circulating antibody capable of protecting mice and agglutinating suspensions of cells grown in the same media, after adsorption with cells grown in media devoid of serum (Gledhill, 1947). Throughout that work the basal medium, to which serum was added, was ordinary meat broth, prepared from fresh horse meat or from a commercial dried preparation with $1 \%$ Evans peptone. Glucose was also added to a concentration of $1 \%$ in the media devoid of serum. While it has been confirmed that such a basal medium is rarely capable of growing cells which, after being killed by formalin or merthiolate, evoke in rabbits circulating antibodies 


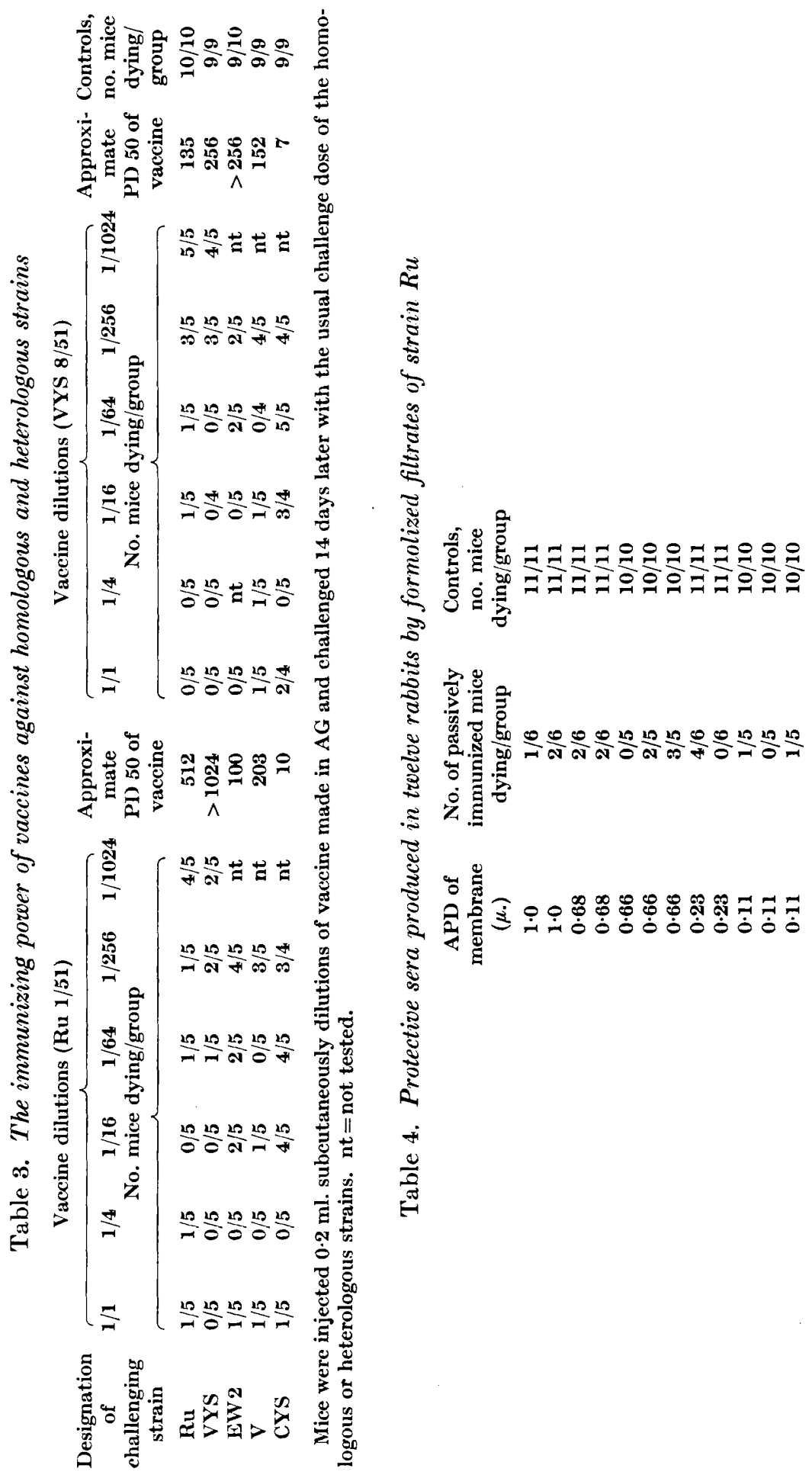


sufficient to protect mice, nevertheless Hartley's tryptic digest broth, especially when containing $1 \%$ glucose, and Wright's broth, are capable of growing cells antigenically active after being killed (Table 5). Although satisfactory

Table 5. The protective power for mice of sera prepared by immunizing rabbits with killed suspensions of strain EW 2 grown in meat broth, Hartley's broth and Hedley Wright's broth

\begin{tabular}{|c|c|c|c|}
\hline $\begin{array}{l}\text { Medium used for growing } \\
\text { immunizing cells }\end{array}$ & $\begin{array}{l}1 \% \text { glucose } \\
\text { added to } \\
\text { mediun }\end{array}$ & $\begin{array}{l}\text { No. of passively } \\
\text { immunized mice } \\
\text { dying/group }\end{array}$ & $\begin{array}{c}\text { Controls, } \\
\text { no. mice } \\
\text { dying/group }\end{array}$ \\
\hline Meat broth & $\begin{array}{l}- \\
+ \\
+ \\
+ \\
+\end{array}$ & \begin{tabular}{l|l}
$6 / 6$ & \\
$6 / 6$ & \\
$5 / 6$ & $23 / 24$ \\
$6 / 6$ & \\
$6 / 6$ &
\end{tabular} & $\begin{array}{c}6 / 6 \\
12 / 12\end{array}$ \\
\hline Hartley's broth & $\begin{array}{l}- \\
- \\
- \\
+ \\
+ \\
+ \\
+\end{array}$ & 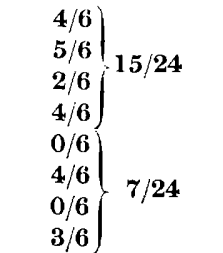 & $\mid 18 / 18$ \\
\hline Hedley Wright's broth & $\begin{array}{l}- \\
- \\
-\end{array}$ & $\left.\begin{array}{l}0 / 6 \\
0 / 6 \\
1 / 6 \\
3 / 5\end{array}\right\} 4 / 23$ & $\left.\right|_{-11 / 11}$ \\
\hline
\end{tabular}

Mice were passively immunized with $0.1 \mathrm{ml}$. intraperitoneally of rabbit serum and were challenged $24 \mathrm{hr}$. later with $\mathrm{EW}^{\prime} 2$ in the usual challenging dose.

growths for vaccine production can sometimes be obtained in media without serum, the presence of serum is advantageous. This similarity in respect of serum in the medium for vaccine production and for producing L-antigen suggested that L-antigen upon the surface of cells might also be free in the medium and that its presence in one or the other locus was essential for producing active vaccine. Support for this hypothesis has been obtained in the following three ways.

(a) While active vaccines can be produced from culture filtrates and while such filtrates evoke in rabbits circulating antibodies able to protect mice, such filtrates after heating fail to manifest activity in either respect. Volumes $(200 \mathrm{ml}$.) of serum $(2.5 \%, \mathrm{v} / \mathrm{v}) \mathrm{HW}$ broth containing $10 \%(\mathrm{v} / \mathrm{v})$ beef liver extract were seeded with strain Ru or strain VYS and incubated for $20 \mathrm{hr}$. at $37^{\circ}$. The cultures were then centrifuged and filtered through Gradocol membranes of $1 \cdot 0 \mu$. APD on membranes of $0 \cdot 61 \mu$. APD. The filtrates from each strain were divided into two portions of $100 \mathrm{ml}$. and one portion heated to $64^{\circ}$ for $1 \mathrm{hr}$. Although it was known that a temperature of $75^{\circ}$ was necessary to destroy L-antigen completely, it was impossible to use a temperature higher than $64^{\circ}$ owing to the serum present in the filtrates. Formalin was then added to heated and unheated filtrates to give a concentration of $0 \cdot 4 \%(\mathrm{v} / \mathrm{v})$. To $50 \mathrm{ml}$. of each portion, $2.5 \mathrm{ml}$. AG was added and $5 \mathrm{ml}$. vaccine prepared. The 
remainder of each portion was used to immunize three rabbits by intravenous injection at 4-day intervals with 1, 2, 3 and $3 \mathrm{ml}$. doses, the rabbits being bled for serum 10 days after the last injection. The results of testing the power of the vaccines to immunize mice actively and of the sera to immunize them passively are shown in Table 6. They clearly support the hypothesis that L-antigen is the active principle in filtrates.

(b) Sera from the above rabbits were also found to be capable of agglutinating suspensions of cells grown in serum $\mathrm{HW}$ broth at titres from $1 / 20$ to $1 / 160$, a fact which shows the filtrates to contain an antigen closely similar to that of the cells. Furthermore, the serum of highest titre against filtrate of each strain was tested for its power to agglutinate cells of strains Ru and VYS grown in ordinary broth media with and without serum. From Table 7 it will be seen that the suspensions grown in medium containing serum were agglutinated, whereas there was no agglutination at $1 / 20$, the lowest dilution, in suspensions grown in medium not containing serum. This result also conforms to the hypothesis that filtrates contain $\mathbf{L}$-antigen.

(c) Cells freed from medium can produce active vaccines, and circulating protective antibodies in rabbits. After heat treatment such cells fail in both respects. That cells can produce active vaccine after centrifugation and re-suspension in saline or fresh medium has been shown seven times with strain $\mathrm{Ru}$, the PD 50's being 19, 35, 6, 23, 4, 37 and 64. In one case (PD 50=23) the cells had been washed three times before being finally suspended in saline. Three vaccines were prepared with VYS cells and these gave PD50's of 4, 81 and 203. Heating saline suspensions of strains Ru and VYS grown in serum HW broth to $64^{\circ}$ for $1 \mathrm{hr}$. rendered them incapable of evoking in rabbits protective antibody for mice, whereas unheated portions of the same suspensions after inactivation with formalin did evoke antibody. Thus, the mortality was six out of six mice challenged after immunization with sera from each of the three rabbits immunized with heated $\mathrm{Ru}$ cells (18/18) as against nil, one, and two out of six mice with sera from each of the corresponding rabbits immunized with unheated Ru cells (3/18). For strain VYS, the mortalities of mice challenged after receiving sera against heated cells were five, six and six out of six mice (17/18) as against nil, nil and one out of six mice (1/18). The vaccines prepared with both the Ru and VYS cells, whether heated or not heated, protected $50 \%$ of mice when diluted $1 / 4$. This result would suggest the possibility that a thermostable antigen rather than $L$-antigen was responsible for the activity of vaccines prepared with cells. However, in view of the fact that the heating was insufficient to destroy the L-antigen it was decided to make fresh vaccines against heated and unheated cells of strains $\mathrm{Ru}$ and VYS, the temperature of heating being raised to $80^{\circ}$ for $\frac{1}{2} \mathrm{hr}$. The PD 50's of the heated vaccines were $<1$ for strain $\mathrm{Ru}$ and for strain VYS as against PD50 values of 37 for strain $R u$ and 81 for strain VYS of the corresponding unheated vaccines. In another similar experiment the PD50's were 1 for strain Ru and 6 for strain VYS as heated vaccines against 64 and 203 for the corresponding unheated vaccines. Having regard to these results and to the low grade activity of the vaccines from the unheated cells in the former 

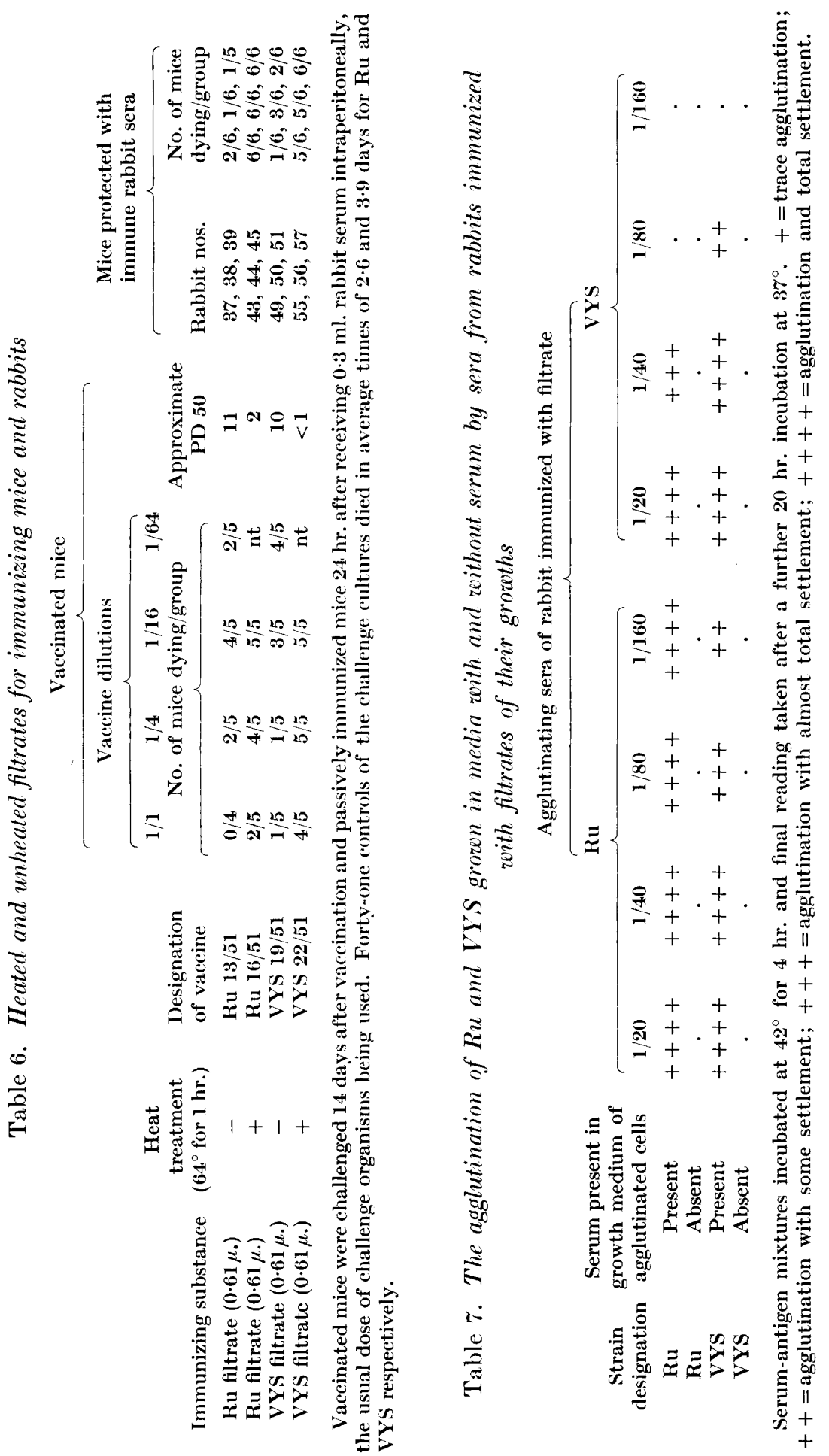
experiment, it seems reasonable to suppose that L-antigen plays an important role in vaccines of high activity prepared with cells. Indeed, it may be that the amount of $\mathrm{L}$-antigen retained by cells is somewhat variable and also the thermostable somatic antigen in itself may yield a vaccine of low activity. If these surmises were correct, then unheated cells giving a vaccine of low activity would probably be cells which had retained little L-antigen and would give a vaccine of almost equal activity after being heated; whereas cells giving a vaccine of high activity would be cells which had retained much L-antigen and so give a vaccine of much reduced activity after heat treatment.

\section{DISCUSSION}

The experiments described confirm Traub's claims that inactivated vaccines capable of effectively immunizing mice can be prepared from cultures of $E$. rhusiopathiae; that only a proportion of strains yield active vaccines; and that soluble antigen, present in the culture fluid after growth, is a necessary component of active vaccines. Reasons have been advanced to show that this soluble antigen is probably the thermolabile L-antigen previously described in association with cells. In cultures capable of yielding highly active vaccines, it seems likely that the ability of the cells to give active vaccines after separation from the culture fluid depends upon the extent to which they have retained L-antigen upon their surfaces. Conversely, filtrates give active vaccines in proportion to the extent that the cells present before filtration had released $\mathrm{L}$-antigen into the medium.

The reason why only a minority of strains yield active vaccines is not clear. Presumably strains which yield active vaccines are strains which produce a sufficiency of fully developed L-antigen in the medium used, whereas strains which do not yield active vaccines do not produce sufficient fully developed L-antigen. Strains not believed to be capable of yielding active vaccines do, however, produce L-antigen when grown in serum-containing media which is sufficient in quantity or quality to render them agglutinable by anti-L sera (Gledhill, 1947). The fact that although on one occasion strain $\mathrm{Ru}$ produced active vaccine in a medium devoid of serum and on other occasions failed to do so, and the fact that strain VYS seems to require liver extract, suggest that all strains in the $\mathrm{S}$-phase might yield active vaccines provided the medium used were suitable. The capacity of $\mathrm{HW}$ broth to grow cells of strain EW 2 which, after killing, produce protective antibodies in rabbits, contrasts with the capacity of ordinary broth, which does not yield cells having this property. The essential difference between HW broth and ordinary broth appears to be that the peptone is added to the former before the meat juices are expressed and boiled, whereas in ordinary broth peptone is added to the complete meat extract. Investigation of the possible toxicity of peptone in relation to the development of L-antigen might lead to a medium capable of growing most strains to yield it satisfactorily. 
I wish to thank Dr A. W. Stableforth for providing me with two valuable strains of E. rhusiopathiae, Mr A. Thomson, M.R.C.V.S., for allowing me to refer to tests of his vaccines in mice, and the late Dr W. J. Elford for providing serum ultrafiltrate. I also gratefully acknowledge the technical assistance of $\mathrm{Mr} \mathrm{A}$. Coe.

\section{REFERENCES}

Bakos, K. von (1951). Über Herstellung und Prüfung eines konzentrierten Adsorbatimpfstoffes gegen den Schweinrotlauf. Nord. vet. Med. 3, 109.

Dinter, Z. von (1948). Uber den Haemagglutinationshemmungstest beim Rotlauf. Berl. Münch. tierärztl. Wschr. $10,113$.

Edwards, C. M. (1949). Polyarthritis in lambs following serum inoculation. Vet. Rec. $61,95$.

Guedhill, A. W. (1945). The antigenic structure of Erysipelothrix. J. Path. Bact. $57,179$.

Gi.edHILl, A. W. (1947). Some properties of a thermolabile antigen of Erysipelothrix rhusiopathiae. J. gen. Microbiol. 1, 211.

Gledhill, A. W. (1948). Reprinted from discussion: swine erysipelas infection (Erysipelothrix rhusiopathiae) in man and animals. Proc. R. Soc. Med. 41, 330.

GLEDHILL, A. W. (1950). Immunization against Erysipelothrix rhusiopathiae with killed vaccine. Nature, Lond. 166, 952.

Reed, L. J. \& Muench, H. (1938). A simple method of estimating fifty per cent end points. Amer. J. Hyg. 27, 493.

Rowlands, W. T. \& EDwards, C. M. (1950). Investigation of further cases of polyarthritis in lambs following serum inoculation. Vet. Rec. 62, 213.

Traub, E. (1947). Immunisierung gegen Schweinerotlauf mit konzentrierten Adsorbatimpfstoffen. Mh. Veterinarmed. 2, 165.

WRIGHT, H. D. (1933). The importance of adequate reduction of peptone in the preparation of media for the pneumococcus and other organisms. J. Path. Bact. 37, 257. 